\title{
INSTITUTIONAL FRAMEWORK FOR PUBLIC UTILITY REGULATION: CASE STUDY OF THE DISTRICT HEATING SECTOR IN UKRAINE
}

Purpose of the paper is to provide the legal analysis of the institutional framework for public utility regulation based on the case study of the district heating sector.

Methods. The analysis of the new paradigm for district heating sector regulation, as well as the institutional framework for district heating sector regulation in Ukraine, is based on the formal logical and deductive methods. These methods also became the basis for making proposals aimed at improving the national legislation that determines the institutional framework for district heating sector regulation.

Results. The first part is focused on the analysis of traditional and modern approaches to structuring and regulation of utilities in the district heating sector. The traditional approach tends to structure and regulate utilities as vertically integrated monopolies. This modern approach offers to separate natural monopoly from the competitive segment of the market and regulate only the natural monopoly segment. The second part highlights the local character of the district heating sector. The author concludes that there is no unified institutional model of district heating sector regulation. Based on the analysis of the legal framework the author concludes that the lack of a comprehensive administrative law concept of state regulation in public utility sector, as well as inadequate legal framework for district heating sector regulation, affects the effectiveness of state regulation.

Conclusions. While the traditional approach tends to structure and regulate utilities as vertically integrated monopolies, the modern approach offers to separate natural monopoly from the competitive segment of the market and regulate only the natural monopoly segment. The modern approach creates a theoretical background for the new paradigm towards district heating regulation. The independent regulatory authority and local public authorities present the institutional framework for district heating sector regulation in Ukraine.

Key words: public utility regulation, independent regulators, local authorities, district heating sector. 


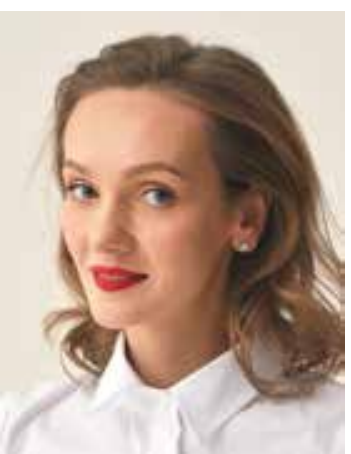

Alona Kazantseva, Clean Energy Leadership Institute Fellow,

Washington D.C. aokazantseva@gmail.com orcid.org/0000-0003-4938-670

\section{Introduction}

District heating sector plays a crucial role in meeting basic heating needs in Ukraine. Despite the importance of the sector, it faces serious problems related to affordability, quality of service, and financial sustainability of the sector. As stated in the World Bank reports, the district heating sector in Ukraine had been heavily subsidized through the provision of natural gas at below-market prices to the utilities that produced heat for residential consumers. Therefore, the cost of residential heat was below the market prices.

Additionally, residential district heating tariffs covered on average of 60 percent of the already low cost of heat production. As a result of low tariffs, district heating companies did not have funds for system modernization and maintenance. Lack of funds negatively affected the quality of heating services. The situation in the sector worsens due to inefficient regulation.

Therefore, this paper aims to provide a legal analysis of the institutional framework for public utility regulation based on the case study of the district heating sector in Ukraine. The tasks of the paper are as follows: to explore the new paradigm for district heating sector regulation and to analyze the institutional framework for district heating sector regulation in Ukraine.

2. New paradigm towards district heating sector regulation

District heating systems are predominantly designed as isolated systems that are not connected. Due to these technological limitations, there is no direct competition between heat suppliers. For many years district heating, together with other network industries, were considered as natural monopolies and therefore were regulated. However, in recent years the approach to utility regulation was changed. Network industries are not treated as monolithic natural monopolies. Instead, they are divided into different activities that allow applying regulation and competition within a single market (Kazantseva, 2018).

District heating is a system of centralized heat production and distribution typically for urban areas. It has already been mentioned above that district heating is a closed system, which consists of heat plants (which often produce heat and electricity simultaneously) and a network of distribution and returns pipes. The heat systems meet residential and commercial needs for space heating and hot water and often provide heat to industry (Mandil, 2004). 
The technological chain allows it to distinguish four different activities within the district heating system: heat production, transmission, distribution, and supply. The traditional approach tends to structure and regulate utilities as vertically integrated monopolies. The modern approach offers to separate natural monopoly from the competitive segment of the market and regulate only the natural monopoly segment.

In the scientific literature, it is a widely accepted opinion that heat transmission, distribution, and supply constitute a natural monopoly segment of the district heating market (Soderholm \& Warell, 2011; Westin \& Lagergren, 2002). Barriers to the market entry and exit are a precondition to natural monopoly status. Extending this approach, $\mathrm{M}$. Wissner argues the following. According to the scholar, free entry means that "newcomers face no disadvantages in terms of production technology and perceived product quality compared to the incumbent". Technically, third party access to district heating distribution grids is possible. However, in practice, it is difficult to ensure free market entry. In contrast to the later, free market exit means that "the company may exit the market without barriers, in particular, that it can recover all the costs incurred when entering the market through sales of the assets used". In general, capital costs for the construction of district-heating distribution grids are substantial. M. Wissner points out that "if competitors built a second heating distribution grids they could hardly earn the costs incurred when leaving the market" (Wissner, 2014). Therefore, district-heating distribution grids, as well as supply networks are not contestable and may be referred to natural monopolies.

In the case of heat production, most scholars support the statement that this activity does not constitute a natural monopoly. Therefore, it allows the introduction of a competitive mechanism. However, opening the market to competition and ensuring non-discriminatory third party access of heat producers to the networks, require the vertical separation between the heat production and heat distribution to the district heating network. Such separation means that the regulation only needs to address the network operations, while the different heat producers will be competing in a mostly free market. However, unbundling is not always possible. The reason is that from an operational perspective production, distribution and supply tend to be tightly integrated.

Furthermore, unlike other network industries, the technology used by district heating makes long distance transmission and supply inefficient. Besides, the district heating sector has a relatively small size of markets that do not allow many entities to operate and compete (Soderholm \& Warell, 2011; Kessides, 2004). During the liberalization of the district heating market, these externalities should be taken into account. In case unbundling is not a feasible solution, indirect form of competition such as competition between sources of heat, wholesale competition, competitive bidding and yardstick competition (benchmarking) could also be considered.

\section{Institutional framework for district heating sector regulation in Ukraine}

The economic and technological characteristics of the public utility sector, together with the level of political and socio-economic development of the country, affect the institutional model of the state regulation. Given the local nature of industries that belong to the public utility sector, the structure and functioning of these industries differ considerably both within a single country and in comparison with other countries. Thus, 
the local nature of the public utility sector causes the lack of a unified approach to the organization, regulation, and financing of the sector.

As stated in the World Bank's report on infrastructure reforms, several decisions are crucial for institutional model of the public utility sector, including the sector competence of regulators, the allocation of regulatory powers between regulator and local authorities, as well as relationship of regulatory authorities with sector ministries and competition or antitrust authorities (Kessides, 2004). These decisions also affect the institutional model for district heating sector regulation.

The institutional framework for district heating sector regulation can be presented by independent regulatory authorities (regulators) or governmental institutions (ministries, agencies, inspections, etc.), as well as municipalities or other local administrations that are responsible for the organization of heating, planning of local infrastructure, approval of investment, price regulation and other practical actions in the organization of centralized heat supply.

It is important to emphasize that the legal status of regulators mainly depends on their role and place in the system of public administration. Thus, regulators may have the status of independent bodies of public administration that do not belong to any of the branches of government, or they can enter the system of executive bodies. Accordingly, if regulators are not organizationally separate from the system of executive bodies, they must still be functionally independent. In some cases, specific functions of utility regulation, in particular, licensing, price and tariff setting, control, etc., are the responsibility of the central executive authorities. However, this practice leads to ineffective regulation, since it makes it impossible to ensure the real independence and accountability of such bodies.

Over the decades, sector ministries were responsible for regulation of the district heating sector in Ukraine. In 2010, a new institutional model of public utility regulation in Ukraine was presented by establishing the public utility regulator. Despite centralization of regulatory powers, licensing and tariff regulation powers were divided between the public utility regulator and local authorities - oblast, Kyiv and Sevastopol city state administrations, as well as local self-government authorities.

The analysis of the Laws of Ukraine allows us to conclude that national legislation does not determine a clear institutional model for public utility regulation. The Law of Ukraine "On Natural Monopolies" considers national commissions for natural monopolies regulation, executive authorities and local self-government authorities as regulatory authorities in the sectors that are natural monopolies. The Law also allows to delegate some regulatory powers to the Council of Ministers of the Autonomous Republic of Crimea, oblast, Kyiv and Sevastopol city state administrations (Verkhovna Rada of Ukraine, 2000).

The Law of Ukraine "On State Regulation in the Public Utility Sector" (Verkhovna Rada of Ukraine, 2010) stipulates that the National Energy and Public Utility Regulatory Commission is the only authority responsible for regulation of public utility sector. At the same time, there are no provisions in the Law regarding the regulatory powers of local authorities. The lack of provisions on the role of local authorities in the regulation of public utility sector can be explained by the fact that when this Law was adopted, it had a title "On the National Commission for Public Utility Regulation of Ukraine". The Law aimed 
at defining the legal basis for the functioning of the public utility regulator. However, in 2011 the Law was amended. As it follows from the new title of the Law as well as from the Preamble of the Law, it determines the legal basis for state regulation in the public utility sector. Therefore, the Law of Ukraine "On State Regulation in the Public Utility Sector" shall include provisions on the role on the role of local authorities in the regulation of public utility sector, as well as clear determine their regulatory powers and relationship with the National Commission for Energy and Public Utility Regulation of Ukraine.

The Law of Ukraine "On Heat Supply" determines that state regulation in the district heating sector is carried out by the Cabinet of Ministers of Ukraine, National Commission for Energy and Public Utility Regulation of Ukraine, the Council of Ministers of the Autonomous Republic of Crimea, oblast, Kyiv and Sevastopol city state administrations (Verkhovna Rada of Ukraine, 2005). Special attention shall be paid to the fact that this list of regulatory authorities in the district heating sector excludes local self-government authorities. However, local self-government authorities play an important role in tariff regulation and their regulatory powers in the district heating sector determined by the Law of Ukraine "On Local Self-governance in Ukraine". The Law of Ukraine "On Heat Supply" specifies the powers of the National Commission for Energy and Public Utility Regulation of Ukraine regarding the regulation of the district heating sector. At the same time, the Law does not define the regulatory powers of the Cabinet of Ministers of Ukraine. Regarding the powers of the Council of Ministers of the Autonomous Republic of Crimea, oblast, Kyiv and Sevastopol city state administrations, the Law mentioned above only determines that these authorities shall carry out licensing and control.

One of the key conclusions is that the lack of a comprehensive administrative law concept of state regulation in public utility sector, as well as inadequate legal framework for district heating sector regulation, affects the effectiveness of state regulation in general. The Law of Ukraine "On State Regulation in the Public Utility Sector" shall clear determine that the National Commission for Energy and Public Utility Regulation of Ukraine is the only regulatory authority that regulates utilities in the district heating sector, water supply, and sewage, as well as municipal waste management sector. The National Commission for Energy and Public Utility Regulation of Ukraine is entitled to delegate certain regulatory powers to local public authorities. These provisions should be reflected in the Law of Ukraine "On State Regulation in the Public Utility Sector" as well as the Law of Ukraine "On Heat Supply".

\section{Conclusions}

The traditional approach tends to structure and regulate utilities as vertically integrated monopolies. This modern approach offers to separate natural monopoly from the competitive segment of the market and regulate only the natural monopoly segment. The separation of natural monopoly from the competitive segments of the market achieved by breaking down of vertically integrated monopolies and unbundling of their activities is not always feasible for the district heating sector. However, some forms of indirect competition still can occur in the sector.

The institutional framework for district heating sector regulation in Ukraine includes the independent regulatory authority and local public authorities. The National Commission for Energy and Public Utility Regulation of Ukraine is the only regulatory authority 
that regulates utilities in the district heating sector, water supply, and sewage, as well as the municipal waste management sector. The National Commission for Energy and Public Utility Regulation of Ukraine is entitled to delegate certain regulatory powers to local public authorities.

\section{Bibliography:}

1. Kazantseva A. The role of regulatory authorities in the promotion of competition in the public utilities sector. Адміністративне право і процес. 2018. № 3 (22). С. 18-29.

2. Mandil C. Coming in from the cold: Improving district heating policy in transition economies. Paris : International Energy Agency, 2004. 262 p. URL: https://www.iea.org/ (access date: 12.10.2017).

3. Soderholm P., Warell L. Market opening and third party access in district heating networks. Energy Policy. 2011. Vol. 39. P. 742-752.

4. Westin P., Lagergren F. Re-regulating district heating in Sweden. Energy Policy. 2002. Vol. 30. P. $583-593$.

5. Wissner M. Regulation of district-heating systems. Utilities Policy. 2014. Vol. 31. P. 63-73.

6. Kessides I. Reforming Infrastructure: Privatization, Regulation, and Competition. Policy Research Report. Washington, DC : World Bank and Oxford University Press, 2004. 325 p.

7. Про природні монополії : Закон України від 20 квітня 2000 р. № 1682-ІІІ / Верховна Рада України. Відомості Верховної Ради України. 2000. № 30. Ст. 238.

8. Про державне регулювання у сфері комунальних послуг : Закон України від 9 липня 2010 р. № 2479-VI / Верховна Рада України. Відомості Верховної Ради України. 2010. № 49. С. 1761. Ст. 571.

9. Про теплопостачання : Закон України від 2 червня 2005 р. № 2633-IV / Верховна Рада України. Відомості Верховної Ради України. 2005. № 28. Ст. 373.

10. Про місцеве самоврядування в Україні : Закон України від 21 травня 1997 p. № 280/97-ВР / Верховна Рада України. Відомості Верховної Ради України. 1997. № 24. Ст. 170.

\section{References:}

1. Kazantseva, A. (2018). The role of regulatory authorities in the promotion of competition in the public utilities sector. Administratyvne pravo i process, no. 3(22), pp. 18-29 [in English].

2. Mandil, C. (2004). Coming in from the cold: Improving district heating policy in transition economies. Paris: International Energy Agency. Retrieved from: https://www.iea.org/ [in English].

3. Soderholm, P., Warell, L. (2011). Market opening and third party access in district heating networks. Energy Policy, vol. 39, pp. 742-752 [in English].

4. Westin, P., Lagergren, F. (2002). Re-regulating district heating in Sweden. Energy Policy, vol. 30, pp. 583-593 [in English].

5. Wissner, M. (2014). Regulation of district-heating systems. Utilities Policy, vol. 31, pp. $63-73$ [in English].

6. Kessides, I. (2004). Reforming Infrastructure: Privatization, Regulation, and Competition. Policy Research Report. Washington, DC: World Bank and Oxford University Press [in English].

7. Verkhovna Rada of Ukraine (2000). Pro pryrodni monopolii: Zakon Ukrainy vid 20 kvitnia 2000 r. № 1682-III [On Natural Monopolies: Law of Ukraine dated April 20, 2000 № 1682-III]. Vidomosti Verkhovnoi Rady Ukrainy, no. 30, art. 238 [in Ukrainian].

8. Verkhovna Rada of Ukraine (2010). Pro derzhavne rehuliuvannia u sferi komunalnykh posluh: Zakon Ukrainy vid 9 lypnia 2010 r. № 2479-VI [On State Regulation in the Field of Utilities: Law of Ukraine dated July 9, 2010 № 2479-VI]. Vidomosti Verkhovnoi Rady Ukrainy, no. 49, pp. 1761, art. 571 [in Ukrainian]. 
9. Verkhovna Rada of Ukraine (2005). Pro teplopostachannia: Zakon Ukrainy vid 2 chervnia 2005 r. № 2633-IV [On heat supply: Law of Ukraine dated June 2, 2005 № 2633-IV]. Vidomosti Verkhovnoi Rady Ukrainy, no. 28, art. 373 [in Ukrainian].

10. Verkhovna Rada of Ukraine (1997). Pro mistseve samovriaduvannia v Ukraini: Zakon Ukrainy vid 21 travnia 1997 r. № 280/97-BP [On Local Self-Government in Ukraine: Law of Ukraine dated May 21, 1997 № 280/97-BP]. Vidomosti Verkhovnoi Rady Ukrainy, no. 24, art. 170 [in Ukrainian].

\title{
ІНСТИТУЦЙНЕ ЗАБЕЗПЕЧЕННЯ ДЕРЖАВНОГО РЕГУЛЮВАННЯ У СФЕРІ КОМУНАЛЬНИХ ПОСЛУГ: НА ПРИКЛАДІ СЕКТОРА ЦЕНТРАЛІЗОВАНОГО ТЕПЛОПОСТАЧАННЯ В УКРАЇНІ
}

\author{
Альона Казанцева, \\ учасник програми Інституту лідерства усфері відновлювальної енергетики, \\ м. Вашингтон \\ aokazantseva@gmail.com \\ orcid.org/0000-0003-4938-6701
}

Мета. Статтю присвячено аналізу інституціийного забезпечення регулювання сфери комунальних послуг на прикладі сектора иеентралізованого теплопостачання.

Методи. Для иілей дослідження автор здійснює аналіз нової парадигми регулювання системи централізованого теплопостачання, а також інституційного забезпечення державного регулювання у сфері теплопостачання в Украӥні шляхом застосування формально-логічного й дедуктивного методів. Ці методи також стали основою для формулюванняпропозиій, спрямованихнавдосконаленнязаконодавства Українистосовно інституиійного забезпечення державного регулювання у сфері теплопостачання.

Результати. Периа частина зосереджена на аналізі традииійних і сучасних підходів до визначення структури сфери теплопостачання та ї̈ регулювання. Традиційний підхід полягає в тому, що підприємства у сфері теплопостачання є вертикально інтегрованими монополіями, які підлягають державному регулюванню. Натомість сучасний підхід пропонує відокремити природну монополію від конкурентного сегмента ринку та регулювати лише монопольний сегмент. Друга частина висвітлює питання щодо особливостей сфери теплопостачання, а саме ї̈ локальний характер. Автор робить висновок про те, щзо не існує єдиної уніфікованої інституційної моделі держсавного регулювання у сфері теплопостачання. На підставі аналізу законодавства Украӥни визначено, щуо відсутність иілісної адміністративної правової концепиії державного регулювання у сфері комунальних послуг, а також неналежне нормативно-правове регулювання його інституиійного забезпечення, щцо проявляється в неузгодженості законодавства, суттєво впливає на ефективність державного регулювання.

Висновки. Сучасний підхід до визначення структури сфери теплопостачання та iї регулювання пропонує відокремлювати природну монополію від конкурентного сегмента ринку та, відповідно, регулювати лише монопольний сегмент. Відтак сучасний підхід визначає теоретичну основу для нової парадигми щзодо регулювання сфери теплопостачання. Інституційна модель державного регулювання у сфері теплопостачання в Україні представлена незалежним органом державного регулювання та місцевими органами публічної влади.

Ключові слова: регулювання сфери комунальних послуг, незалежні регулятори, місцеві органи публічної влади, сфера теплопостачання. 